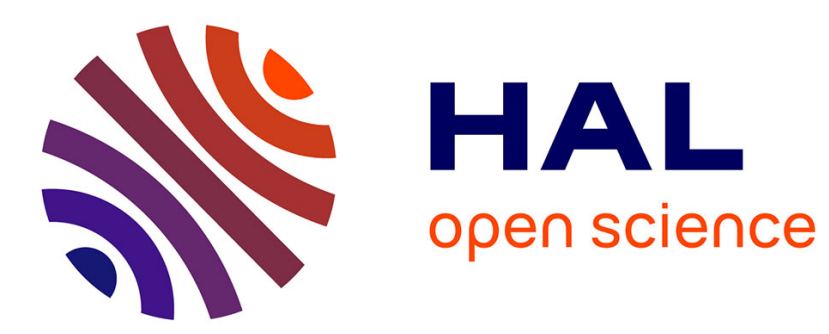

\title{
Do remittances support consumption during crisis? Evidence from Kosovo
}

Laetitia Duval, Francois Charles Wolff

\section{To cite this version:}

Laetitia Duval, Francois Charles Wolff. Do remittances support consumption during crisis? Evidence from Kosovo. 2016. hal-01278930

\section{HAL Id: hal-01278930 \\ https://hal.science/hal-01278930}

Preprint submitted on 29 Feb 2016

HAL is a multi-disciplinary open access archive for the deposit and dissemination of scientific research documents, whether they are published or not. The documents may come from teaching and research institutions in France or abroad, or from public or private research centers.
L'archive ouverte pluridisciplinaire HAL, est destinée au dépôt et à la diffusion de documents scientifiques de niveau recherche, publiés ou non, émanant des établissements d'enseignement et de recherche français ou étrangers, des laboratoires publics ou privés. 


\title{
Imperial College
} London

\section{Do remittances support consumption during crisis? Evidence from Kosovo}

\author{
Laetitia Duval
}

\author{
François-Charles Wolff ${ }^{* *}$
}

\begin{abstract}
This paper focuses on the effect of remittances on per capita consumption over time in a context of conflict, war-to-peace transition and crisis. We use two household surveys from Kosovo with unique timing, one collected immediately after the civil war in 2000 and the other during the economic crisis in 2010. This territory, in which the tension among ethnic groups is the focus of international concern, is one of the top remittance-receiving countries in the world. We examine the effect of remittances not only at the average level of consumption, but also at various parts of the distribution of consumption using quantile regressions. We find that remittances alleviate poverty by enhancing the consumption level of the most vulnerable households, and the positive effect of remittances on consumption has remained constant between 2000 and 2010 . This result may be connected with the resilience of remittances.
\end{abstract}

JEL classification: I32, D12, 015

Keywords: Remittances, consumption, poverty, economic crisis, Kosovo

\footnotetext{
\# We are indebted to two anonymous reviewers for their very helpful comments and suggestions on previous versions of the manuscript. Any remaining errors are ours.

* Corresponding author. Imperial College London, School of Public Health, St Mary's Campus, Norfolk Place, London W2 1PG, United Kingdom. E-mail: I.duval@imperial.ac.uk

${ }^{* *}$ LEMNA and INED, Université de Nantes, Chemin de la Censive du Tertre, 44322 Nantes Cedex 3, France.

E-mail: francois.wolff@univ-nantes.fr
} 


\section{Introduction}

International migration has many implications for developing countries, one of the most significant being remittances. Remittances are associated with significant development impacts such as reduced depth and severity of poverty (Adams and Page, 2005; Adams et al., 2008), improved school attendance (Edwards and Ureta, 2003) and healthcare (Hildebrandt and McKenzie, 2005), the facilitation of housing investment (Osili, 2004), as well as the generation of investment among small enterprises (Woodruff and Zenteno, 2007). Whether such benefits hold for recipient households living in countries experiencing shocks such as conflicts has been little explored, mainly due to the lack of appropriate micro-level household data ${ }^{1}$.

In this paper, we assess the effect of remittances on per capita consumption in post-civil war and crisis contexts using two household surveys in Kosovo. We ask: Do remittances from overseas migrants support consumption over time for relatives left at home? Kosovo provides a unique setting to study the relationship between consumption and remittances. Since the 1990s, Kosovo has been in a process of transition from a communist system to a market economy and from ethnic violence to peace, which has led to severe vulnerability among the population. Serbs and Albanians were involved in a civil war in the 1990s in this territory of former Yugoslavia, giving rise to population displacements, casualities of war and widespread destruction. Kosovo is still characterized by ethnic tensions and a combination of extreme poverty and lack of job opportunities, with a high rate of emigration.

In that context, remittances play an important role in supporting those family members who have decided to stay in Kosovo, which may be critical for people with very low levels of income. With respect to previous studies, an issue of particular interest for us is to learn whether the motivation behind migration has an influence on the remittances-consumption nexus. Researchers usually focus on developing countries where migrants leave their place of origin in order to escape poverty (Adams and Page, 2005; Adams et al., 2008). In such circumstances, migrants seek to cover the basic needs of their family members who are left behind. In Kosovo, the situation seems different as migration decisions are strongly related to ethnic and political considerations in addition to economic reasons. This specific pattern could affect the reasons explaining why Kosovan migrants send money to their origin country. For instance, remittances may be used to cover the migration costs of other family

\footnotetext{
${ }^{1}$ A few studies have examined how remittances supported household consumption following natural disasters. Yang and Choi (2007) find that remittances serve as insurance following rainfall shocks in the Philippines, while Mohapatra et al. (2012) show that that per capita consumption is higher in remittance-receiving households than in others after the 1998 flood in Bangladesh.
} 
members seeking to live far from Kosovo because they do not feel safe due to ongoing ethnic tensions ${ }^{2}$.

In this paper, we provide evidence on the role remittances play vis-à-vis consumption by first using an unusually rich data set collected in 2010 by the United Nations Development Programme (UNDP) among 4,000 households. In addition, we use the Living Standard Measurement Study (LSMS) conducted by the World Bank among 2,800 households at a unique point in time: the year after the end of NATO bombing campaign in 2000. We combine both surveys to study whether the effect of remittances on consumption has changed over the period 2000-2010. While previous studies have essentially focused on the average level of consumption, in order to study the effect of remittances on poverty (Adams and Cuecuecha, 2010a; Adams and Cuecuecha, 2010b), we rely instead on a quantile regression framework. This allows us to assess the effect of remittances in various parts of the consumption distribution as we expect higher benefits from these financial transfers for the less well-off households.

We proceed in the following way in our empirical analysis: Firstly, we describe the pattern of remittances in Kosovo using the detailed dataset we have for the year 2010. We measure the effect of remittances on consumption at, respectively, the bottom, median and top of the distribution of consumption using quantile regressions. We show that remittances strongly contribute to economic welfare by enhancing the consumption level of the poorest households the most. Secondly, we investigate the possibility of changes in the consumption-remittances relationship between 2000 and 2010. We find that the positive effect of remittances on consumption has remained constant over that period despite the different motives of migration in this post-civil war context.

The remainder of our paper is organized as follows: In Section 2, we highlight the theoretical background behind the link between remittances and consumption and present the Kosovan context. In Section 3, we describe the data along with the pattern of remittances and consumption. We outline our empirical strategy in Section 4 where we report estimates of the effect of remittances at various percentiles of the consumption distribution using the 2010 data. In Section 5, we investigate whether the effect of remittances on consumption has changed between 2000 and 2010. Finally, Section 6 concludes.

\section{Background and context in Kosovo}

Understanding the effect of remittances on the welfare of households living in different developing countries requires detailed micro-level data which are not often available for empirical

\footnotetext{
${ }^{2}$ In Bosnia-Herzegovina, Dimova and Wolff (2015) show that remittances tend to increase the migration prospects of their recipients.
} 
research ${ }^{3}$. On the key issue of how remittances are spent by households, results are mixed and vary strongly across countries. In Indonesia, Adams and Cuecuecha (2010a) find that recipients tend to spend more at the margin on food and less on education and housing than non-recipients, while these results are reversed in Guatemala (Adams and Cuecuecha, 2010b). It is therefore important to investigate further the transfers from overseas migrants for households living in different developing countries as the local context may play a substantial role.

Brown and Jimenez (2008) have attempted to explain why previous findings in the literature are mixed. They argue that this is due to the migration histories. In the early stages of migration patterns, international migrants are not randomly distributed across income groups. It is not the poorest households who migrate but the middle-lower, because of the high cost of migration (Arango et al., 1996). However, with the development of migrant networks in the destination countries, international migration covers all income groups. Previous studies have shown that migrant networks play an important role in the migration decisions of potential migrants (Epstein and Gang, 2006; Dolfin and Genicot, 2010). These networks facilitate further migration by providing specific employment information, accommodation and supportive relationships and by offering services which help reduce the costs of migration.

In our review of the general literature, we found that very few studies consider the cases of conflict, war-to-peace transitions and crisis contexts. It can be argued that these contexts face much the same issues as when migrants send remittances to developing countries where the population is poor, unemployment is high and life is prone to many kinds of risk, such as income loss due to weather-related events. There are, however, a few key differences.

Firstly, while policies in a number of remittances-receiving countries encourage development uses of remittances (such as in Mexico and the Philippines), this is not the case in Kosovo because of the absence of functioning government and financial institutions since the civil war. Secondly, forced migration brought about by conflict not only leads to job losses, but can also disrupt established social networks. Thirdly, when government and financial institutions are not operating appropriately, transferring remittances is difficult and costly, meaning that transfers are likely to take place through informal means. Paradoxically, this may put more money directly into the hands of families who receive remittances sent by overseas migrants.

We now turn to the Kosovan context. In 1989, Serbia revoked Kosovo's autonomy as a province. Throughout the 1990s, the Albanian "Kosovo Liberation Army" (KLA) sought the independence of Kosovo. In 1998, the Serbian army conducted an offensive against the KLA with the

\footnotetext{
${ }^{3}$ For an extensive analysis of the determinants of remittances and their motives, see Rapoport and Docquier (2006) and Piracha and Saraogi (2012).
} 
aim of creating an ethnically homogenous Serb territory. This resulted in high levels of violence, victims and population displacements. Due to the successive wars in the former Yugoslavia (Slovenia, Croatia and Bosnia and Herzegovina from 1991 to 1995), NATO decided on air force operations against the Serbian army. In June 1999, the UN Security Council Resolution 1244 decided to place Kosovo under a protectorate - the UN Interim Administration Mission in Kosovo. The Assembly of Kosovo declared unilateral independence in February $2008^{4}$.

The case of Kosovo provides a very interesting case study for remittances as this territory experienced high levels of emigration during and after the civil war, which places Kosovo among the countries with the largest emigration in relation to its total population (around 20\% (UNDP, 2011)). In Kosovo, two main ethnic groups live separated from each other: Albanians who are Muslim and speak Albanian, and Serbs who are Orthodox and speak Serbian ${ }^{5}$. The relationship between the two ethnic groups is very tense and is the focus of international concern (Bhaumik et al., 2006). Clashes between Albanians and Serbs occur regularly, which requires the intervention of NATO's KFOR forces.

In most developing countries where the link between remittances and consumption has been investigated so far, migration essentially has an economic motivation (Adams and Cuecuecha, 2010a; Adams and Cuecuecha, 2010b). Many migrants leave their origin country in order to escape poverty and to help their family members left at home. The situation is very different in Kosovo as migration has fueled existing ethnic rivalries. Population displacements, destruction of housing and difficult access to education and health have resulted in high vulnerability of the population (World Bank, 2001). During the 1990s, a large proportion of Albanians from Kosovo was displaced either internally or abroad, mainly to neighbouring countries such as Albania, Macedonia and Montenegro (European Stability Initiative, 2006).

Emigration has continued in the post-war period as well. Living standards in Kosovo are among the lowest in Europe. According to the Household Budget Survey in 2009 (UNDP, 2011), more than one-third of the population still lives below an absolute poverty line of $€ 1.55$ per adult equivalent per day, and $12 \%$ live below an extreme poverty line (€1.02). In addition - and contrary to demographic trends in the rest of Europe - the Kosovan population is young, with an estimated onehalf of the population younger than 25 years of age. The main problem is that the post-conflict reconstruction did not generate employment opportunities, and the unemployment rate was estimated at $46 \%$ in 2009 .

\footnotetext{
${ }^{4}$ Over 80 countries recognized the independence of Kosovo, with the exception of Serbia and Russia. However, the status of Kosovo currently remains undetermined.

${ }^{5}$ According to the last census conducted in 2011, Kosovo was estimated to have a population of around 1.7 million people, of whom approximately $88 \%$ were Albanians and $8 \%$ Serbs (UNDP, 2011).
} 
Presently, Western European countries such as Italy, Germany and Switzerland are the main destinations of Albanians from Kosovo (UNDP, 2011). Ethnic conflict continues to be a problem leading to emigration, in addition to economic reasons. While Kosovo remains numerically dominated by Albanians, there are some Serb enclaves mainly in the North at the border with Serbia. Ethnic tensions, lack of security, and dissatisfaction with Kosovan political institutions appear to be the main drivers of Serb emigration today (European Stability Initiative, 2006).

\section{Data and descriptive statistics}

We begin our empirical analysis with data from the Kosovo Remittance Study 2010 which was carried out by the UNDP on a representative sample of 4,000 households. This survey was organized in several distinctive parts in order to collect specific types of information. The first part captures general household characteristics such as gender, age, ethnicity, marital status, years of education and employment status of each household member. The head of the household further indicated the amount of monthly household income, along with the amount and composition of monthly expenditures.

The second part of the survey provides detailed information related to the receipt of remittances. We know the relationship between the donor and the head of the household (spouse, children, siblings, etc.), where the donor lives, the duration of migration and the legal status of the donor in the host country. Also, the survey contains a few questions about the characteristics of remittances: amount (either in cash or in kind), frequency, reception channel, knowledge of the recipient on transfer costs, expectations to receive transfers from abroad in the future, and a selfreported assessment of the remittance contribution to economic welfare. The third part of the survey describes the use of remittances. There are seven possible categories of expenditures: current consumption, other consumption, housing investment, human investment, business investment, savings, and debt repayment.

Here we describe the pattern of remittances in Kosovo. Overall, the proportion of households receiving either financial or in-kind transfers from abroad was $17.7 \%$ in 2010 . The value of financial transfers was higher than that of in-kind transfers. On average, recipients benefited from $€ 2,821$ of cash and $€ 1,861$ of in-kind remittances. A breakdown by ethnicity shows that the rate of transfers was much higher among Albanians (21\%) than among Serbs (6\%) and other minorities (10.9\%). Also, Albanians and Serbs received on average higher amounts of remittances compared to 
the other minorities: the value of in-kind remittances was equal to €133.7 for Albanians, €48.8 for Serbs and $€ 15.8$ for other minorities ${ }^{6}$.

As shown in Figure 1, more than half of the transfer amount $(54.5 \%)$ is spent on current consumption to buy food, clothing or services and utilities. It is followed by human investments $(13.8 \%)$, other consumption (13.3\%) such as household durables, then housing investments $(8.1 \%)$. Less money is devoted to business investments (4.1\%), debt repayment (3.6\%) or savings $(2.6 \%)$. Our results show interesting differences by household income level. Among recipients with the lowest monthly income (less than €200), remittances are more often used for current consumption (58.7\%) and human investments (14.8\%). Conversely, the richest recipient households (defined as those reporting more than $€ 600$ per month) spend much more on business investment than the poorest ones (10.1\% compared to $2.5 \%)$.

\section{Insert Figure 1 here}

Next, we assess the contribution of remittances to total household resources. The average transfer amount is $€ 609.5$ and the average annual income is $€ 4,358$. The contribution of money from abroad amounts to $12.3 \%$ at the sample mean. However, there are substantial differences between households depending on their position in the income distribution. In Figure 2, we report the contribution of remittances to total resources as a function of household income deciles. For the first decile, remittances contribute more than $60 \%$ to the level of monthly household resources $(61.3 \%)$. For the second and third deciles the contribution is about one third of this figure $(20.7 \%$ and $25.3 \%$, respectively). Conversely, the contribution of remittances remains rather stable when considering the other income deciles (at around 10\%).

\section{Insert Figure 2 here}

It is interesting to compare this objective contribution of remittances with a more subjective assessment self-reported by recipients. Specifically, we rely on the following question asked to recipients: "What is the contribution of remittances to your household economic welfare?". Possible answers are "very small" (less than 15\%), "small" (between 16\% and 35\%), "mid-level" (between 36\% and 65\%), "large" (between 66\% and 85\%) and "very large" (over 85\%). As shown in Table 1, recipients claim that on average the contribution of remittances to their economic welfare is high: $42.8 \%$ of answers are at the "mid-level", $22.9 \%$ at the "large" level, and $14.2 \%$ at the "very large" level. When relating these answers to the level of household income, we find that the influence of remittances on economic welfare is more often at the "mid-level" for the three selected income

\footnotetext{
${ }^{6}$ Using another dataset collected in Kosovo in 2011, Duval and Wolff (2015) investigate more closely the role played by ethnicity on the remittance pattern. They show that the probability of receiving money from abroad is much higher for Albanians compared to Serbs.
} 
groups. This proportion is $42.8 \%$ in the lowest income group (less than $€ 200$ ), $44.4 \%$ in the second group (from $€ 200$ to $€ 600$ ) and $37.2 \%$ in the highest (more than $€ 600$ ) ${ }^{7}$.

Insert Table 1 here

The average consumption expenditure per household amounts to $€ 385$. We take both the size of the household and the age composition of its members to compute an adjusted level of consumption per capita. For that purpose, we apply a standard OECD equivalence scale ${ }^{8}$. The log of consumption per capita is equal to 4.622 for the whole sample. This average value is 4.705 among recipients and 4.604 among non-recipients, meaning that the average level of consumption is associated with a rise of 10.1 percentage points among those who have benefited from some financial support from abroad. This gap varies strongly along the consumption distribution. It amounts to $47.5 \%$ at the $1^{\text {st }}$ percentile, $28 \%$ at the $5^{\text {th }}$ percentile and $17.4 \%$ at the $10^{\text {th }}$ percentile, but is $9.5 \%$ at the $25^{\text {th }}$ percentile. It ranges between $6 \%$ and $10 \%$ for the other percentiles.

We consider a large set of demographic and socio-economic household characteristics in order to explain the level of household consumption: gender, age, marital status, size and age composition of the household, education and employment status of the head, whether living in an urban area, ethnicity and regional dummies (see Table 2). There are few female-headed households in our sample (15.5\%). Respondents are 49 years old on average, most of them are married $(84.5 \%)$, and $46.1 \%$ have completed secondary school and $25.7 \%$ more than secondary school. In terms of employment, $24.2 \%$ are unemployed, $19.3 \%$ are employed in the public sector, $30.8 \%$ work in the private sector and $8.1 \%$ are employers or self-employed. Of the other characteristics, $51.7 \%$ of respondents live in an urban area, $75.2 \%$ are of Albanian origin, $15 \%$ are Serb and $9.8 \%$ are from another ethnic minority.

\section{Insert Table 2}

Table 2 also includes a description of the sample by transfer receipt status. Respondents who received money are more often women and older. They are less educated and have a much higher probability of being unemployed (34.4\% compared to $22 \%$ ). Conversely, they are less often employed in either the public $(-6.3 \%)$ or the private $(-8.3 \%)$ sector. This pattern suggests that remittances are most often targeted to the most vulnerable people. In what follows, we turn to an econometric analysis to investigate the effect of remittances on welfare net of the role played by these household

\footnotetext{
${ }^{7}$ This contribution is more often either "large" or "very large" in both the lower and upper groups of income which differs from what was obtained using the more objective indicator measuring the contribution of remittances to total income. The subjective question refers to the concept of economic welfare which may be more difficult to appreciate.

${ }^{8}$ The OCDE equivalence scale assigns a value of 1 to the head of the household, of 0.7 to each additional adult and of 0.5 to each additional child (aged 0 to 17 years).
} 
characteristics. Following the pattern described in Figure 2, our analysis focuses on the effect of transfers from abroad over the whole distribution of per capita consumption.

\section{Estimates from quantile regressions}

We study the impact of remittances on consumption using quantile regressions. Introduced by Koenker and Bassett (1978), quantile regressions are models which describe the impact of covariates at various parts of the conditional distribution of the outcome of interest. In our context, these regressions will shed light on the influence of remittances at, respectively, the bottom, the median and the top of the distribution of per capita consumption.

Let $C_{i}$ be the logarithm of per capita consumption for household $i$. We denote by $Q_{q}\left(C_{i} \mid R_{i}, X_{i}\right)$ the conditional $q^{\text {th }}$ quantile regression function, where $R_{i}$ is a dummy variable measuring the receipt of remittances and $X_{i}$ is a set of control variables. Assuming that the conditional quantile regression $Q_{q}\left(C_{i} \mid R_{i}, X_{i}\right)$ is linear in $R_{i}$ and $X_{i}$, the model which we estimate is:

$$
Q_{q}\left(C_{i} \mid R_{i}, X_{i}\right)=\delta_{q} R_{i}+X_{i} \beta_{q}
$$

The quantile regression estimators $\delta_{q}$ and $\beta_{q}$ are solutions to an optimization problem solved by linear programming methods. In (1), $\delta_{q}$ and $\beta_{q}$ indicate the estimated returns to, respectively, the receipt of remittances and other covariates at the $q^{\text {th }}$ quantile of the consumption distribution.

As a preliminary step, we study the effect of the explanatory variables on the conditional mean of per capita consumption using Ordinary Least Squares. As shown in the first column of Table 3 , gender, age and marital status of the head of the household have no particular influence on the average level of consumption. Consumption is negatively correlated with the size of the household. Per capita consumption is higher when the head has a good economic position. The average level increases by around $4 \%$ when the head has achieved a secondary school education and by $13 \%$ for heads with higher education. Consumption is significantly reduced when the head is unemployed $(-8 \%)$, while having a job improves the situation within the household with a rise exceeding $15 \%$. Respondents from other minorities consume less on average compared to Albanians.

Insert Table 3 here

We also introduce receipt of remittances as an exogenous covariate in the OLS regression. Results show a positive relationship between remittances and consumption (significant at the $1 \%$ level). Transfers from abroad strongly contribute to the economic welfare of households in Kosovo since the consumption per capita is $18.2 \%$ higher for recipients ${ }^{9}$. Interestingly, this increased

\footnotetext{
${ }^{9}$ Since our dependent variable is expressed as a logarithm, the coefficient $\delta_{O L S}$ of remittances reported in Table 2 cannot be interpreted as the proportional change in $C_{i}$ resulting from a unit change in $R_{i}$. As shown in Thornton and Innes (1989), the correct change in $R_{i}$ is given by $\exp \left(\delta_{O L S}\right)-1$.
} 
consumption varies along the consumption distribution. In Table 3, we report coefficients from conditional quantile regressions estimated at, respectively, the $10^{\text {th }}, 25^{\text {th }}, 50^{\text {th }}, 75^{\text {th }}$ and $90^{\text {th }}$ percentiles. We find that the role played by transfers from abroad is much higher at the bottom than at the top of the consumption. This means that poorer households benefit more than richer households from remittances in terms of additional consumption per capita. Specifically, the level of consumption increases by $22.4 \%$ at the $10^{\text {th }}$ percentile, $16.9 \%$ at the $25^{\text {th }}$ percentile and $14.3 \%$ at the $50^{\text {th }}$ percentile. The rise is $14.5 \%$ at the $75^{\text {th }}$ percentile and $12.2 \%$ at the $90^{\text {th }}$ percentile.

We further investigate the effect of remittances on per capita consumption using quantile treatment effects (QTE). Several estimators exist for QTE (Frölich and Melly, 2010). We have to distinguish between conditional and unconditional effects with either an exogenous or endogenous treatment variable. Conditional QTE are conditional on a set of explanatory variables $X$, while unconditional effects indicate the causal effect of a treatment for the entire population. When the treatment choice is supposed to be exogenous, this corresponds to a selection on observables framework (matching assumption). When the treatment is viewed as endogenous, an instrumental variable is needed. This instrument should be highly correlated with the receipt of transfers from abroad, but not with consumption. Unfortunately, the survey offers no convincing possibility to adopt such an approach. As a consequence, we rely on a selection on observables setting. Exposure to treatment is supposed to be random within cells defined by observed covariates $X$.

With a linear model, the conditional QTE of $R_{i}$ is given by the coefficient $\delta_{q}$ in (1) and is obtained using the quantile regression estimator of Koenker and Bassett (1978). These estimates were reported in Table 3 and have already been discussed. The unconditional QTE is $\Delta_{q}=Q_{q}^{C^{1}}-Q_{q}^{C^{0}}$ (Firpo, 2007). Although the definition of $\Delta_{q}$ does not depend on $X$, the covariates $X$ are still used to estimate the unconditional QTE as they make the identification assumption more plausible ${ }^{10}$. We find that the unconditional QTE estimates strongly decreases along the distribution of consumption. At the $10^{\text {th }}$ percentile, the receipt of remittances increases per capita consumption by $25.1 \%$. This marginal effect is more than twice lower at the $25^{\text {th }}$ percentile $(11.0 \%)$ and not significant in the upper part of the distribution (above the $75^{\text {th }}$ percentile).

An explanation of this decreasing trend along the consumption distribution is that the additional income received through remittances is vital for very poor and poor families to purchase more food and goods in order to fulfill their basic daily needs. Conversely, among wealthy households, part of the financial transfers may be saved in a bank or invested in business. If our

\footnotetext{
${ }^{10}$ The estimation procedure includes two steps. The first is a nonparametric estimation of the propensity score explaining $\operatorname{Pr}(R=1 \mid X)$. The second is a computation of the difference between two quantiles which is obtained using a propensity-score weighting estimator (Frölich and Melly, 2010).
} 
interpretation is correct, then substantial differences should be observed even in the lower part of the consumption distribution. To assess how very poor households are dependent on transfers received from migrants, we plot in Figure 3 the unconditional QTE estimates under exogeneity along the distribution of per capita consumption. Clearly, the consumption-enhancing effect of remittances is much larger in the first decile and to a lesser extent in the second decile. The QTE estimate of remittances is above $40 \%$ in the first two percentiles, above $30 \%$ at the $5^{\text {th }}$ percentile and above $20 \%$ at the $10^{\text {th }}$ percentile. The profile is rather flat above the $20^{\text {th }}$ percentile.

Insert Figure 3 here

\section{Economic crisis and the consumption-enhancing effect of remittances}

The economic situation in Kosovo has improved since the end of the civil war in 1999, supported in part by international donors and large investments during the post-conflict reconstruction. Nevertheless, high unemployment and severe vulnerability of households are still major challenges in Kosovo (UNDP, 2011). During the recent global economic crisis, Kosovo has not been as strongly affected as other countries in Central and South-East Europe. The average annual growth remained positive in 2009 (2.9\%) and continued to increase in 2010 (4.0\%). An explanation for this is that Kosovo is a small size economy with a low level of integration into the global economy. However, the international economic slowdown in developed countries has led to indirect costs for Kosovo because that country is highly dependent on international donors and transfers from overseas migrants. Furthermore, the rise in unemployment in the destination countries of Kosovan migrants (mainly Western European countries) has affected remittances ${ }^{11}$.

Given the global economic crisis, it is worth knowing whether there has been any change over recent years in the effect of remittances on the level of per capita consumption in Kosovo. It is important to note that it is difficult to have any baseline knowledge concerning the role of economic conditions on the consumption-remittances relationship because no studies on this issue have been conducted before. On the one hand, in a strong economic growth environment, households living in Kosovo should have more opportunities to find a well-paid job and their private consumption should be less dependent on transfers received from abroad. On the other hand, if migrants also face better economic conditions in the destination country, they may send larger amounts of remittances to their family members living in the origin country. Clearly, negative economic shocks will affect the

\footnotetext{
${ }^{11}$ The World Bank (2013) has highlighted the resilience of remittances. The decline of remittances for developing countries was very low in 2009 compared to other resource flows. For instance, foreign direct investments fell to 40\% between 2008 and 2009. According to Mohapatra et al. (2010), two main reasons explain why remittances are persistent over time. Firstly, remittances are sent by cumulated flows of migrants, not only by new migrants during one year. Secondly, border controls and fear of unemployment encourage migrants to stay abroad.
} 
situation of both residents in the country of origin and migrants in the host country in the reverse direction.

Our study focuses on changes in the consumption-remittances relationship during the 2000s using a second dataset: the Kosovo LSMS survey carried out between September and December $2000^{12}$. The sample, which was designed to be representative of urban and rural areas, includes 2,880 households. In contrast to the Kosovo Remittance Study 2010, the 2000 LSMS survey was not specifically designed for the purpose of analyzing remittances. However, it contains questions on the migration history of households and displacements during the civil war. In what follows we describe the information from the LSMS of most relevance for our analysis, bearing in mind that similar questions in both datasets are needed for the comparison.

Firstly, the Kosovo LSMS survey includes information on the demographic and socioeconomic characteristics of households: gender, age, ethnicity, marital status, size, education, employment status and location. Secondly, information on remittances is available from the module on private inter-household transfers. The definition of the transfer variables includes both remittances and transfers from family members living in Kosovo. As we know where the potential donors live, we can isolate transfers from abroad from inter-household transfers flowing between family members living in Kosovo. Thirdly, we rely on the consumption module to obtain the level of per capita consumption, which includes consumption of food, consumer goods, durable goods, housing and expenditures on health and education.

On average, the level of per capita household consumption was higher among recipients than non-recipients in $2000^{13}$. The difference amounts to $11.8 \%$ (4.512 among recipients compared to 4.394 among non-recipients). Again, the gap is more pronounced in the lower part of the consumption distribution: 19.7 at the $5^{\text {th }}$ percentile, $20.4 \%$ at the $10^{\text {th }}$ percentile and $15 \%$ at the $25^{\text {th }}$ percentile. It is equal to $11.6 \%$ at the median and much lower above the median. Since we have the same information in the 2000 and 2010 data, we can compare the impact of remittances on consumption for both years. For that purpose, we pool the two datasets and construct a dummy variable $S_{i}^{10}$ such that $S_{i}^{10}=1$ when the respondent $i$ is interviewed in 2010, and $S_{i}^{10}=0$ otherwise. Still assuming that remittances are exogenous, we estimate the following conditional quantile regressions:

$$
Q_{q}\left(C_{i} \mid R_{i}, X_{i}\right)=\delta_{q} R_{i}+\vartheta_{q} S_{i}^{10}+\kappa_{q} R_{i} * S_{i}^{10}+X_{i} \beta_{q}
$$

\footnotetext{
${ }^{12}$ For further information on the Kosovo LSMS survey, see http://www.worldbank.org/lsms/index.htm.

${ }^{13}$ In an appendix available upon request, we present results similar to those described in Tables 2 and 3 but obtained using the 2000 LSMS data.
} 
with $\vartheta_{q}$ and $\kappa_{q}$ coefficients to estimate. For the $q^{\text {th }}$ quantile of the consumption distribution, the coefficient $\kappa_{q}$ indicates whether or not the influence of remittances has changed between 2000 and 2010. If for instance $\kappa_{q}$ is positive and significant, this means that the enhancing-effect of transfers on consumption has increased between 2000 and 2010.

Estimates of the quantile regressions including the transfer-year interaction term are reported in Table 4 for the $10^{\text {th }}, 25^{\text {th }}, 50^{\text {th }}, 75^{\text {th }}$ and $90^{\text {th }}$ percentiles, respectively. Firstly, as previously emphasized, the effect of the receipt of remittances decreases along the consumption distribution. The transfer coefficient at the median of the distribution is about half that of the $10^{\text {th }}$ and $25^{\text {th }}$ percentiles. In both years, these two percentiles are mostly poor households who benefit from the receipt of money from abroad in terms of welfare improvement. Secondly, while the level of per capita consumption increased between 2000 and 2010, the interaction term crossing the receipt of remittances by the year dummy is never significant at conventional significance levels. This means that the positive effect of remittances on the level of per capita consumption has not changed between 2000 and $2010^{14}$.

Insert Table 4 here

An explanation of this puzzling result could be that the global economic crisis had an impact both on the incomes of migrants in the host country and on the family resources remaining in the country of origin. While those left behind were in a more needy position due to the deteriorated economic situation in Kosovo, potential migrant donors also had to deal with more difficult labour market conditions and were unable to provide more help to their family members. While remittances are a complex function of both donor's and recipient's levels of resources (Rapoport and Docquier, 2006), there may also be some norms of social support such that migrants absolutely have to send money to poor household members so that the latter can eat and survive.

\section{Conclusion}

The purpose of our paper was to study the effect of remittances on per capita consumption for recipient households living in a context of conflict, war-to-peace transition and economic crisis. We explored this issue using the Kosovo Remittance Study conducted by the UNDP in 2010 and the Kosovo LSMS survey provided by the World Bank in 2000. We examined possible changes in the consumption-remittances relationship over time using quantile regressions. Our main results are twofold. Firstly, remittances significantly improve the living standard of recipient households,

\footnotetext{
${ }^{14}$ For the sake of robustness, we have estimated the quantile regressions augmented by the transfer-year of survey interaction term for the first ten percentiles. In each of these regressions, the interaction term was very low and never significant.
} 
especially for the most vulnerable households. Secondly, we find that the positive contribution of remittances to consumption in Kosovo has remained constant between 2000 and 2010. This result was not necessarily expected due to changes in economic conditions arising from the recent global economic crisis, but it may certainly be connected with the resilience of remittances as emphasized by the World Bank (2013).

It is worth asking if our findings are specific only to the case of Kosovo, of if they have wider application. We believe that the context under investigation is typical of the majority of post-civil war countries with frequent political and economic crises, where diaspora contributions are of crucial importance for households who remain in their origin country. Kosovo is characterized by a complex migratory context in a situation of deep ethnic divisions. This former territory of Yugoslavia has for years contributed to migration movements in Europe, but over the last decade migration has increased, for a range of reasons, including conflict displacement, the search for political refuge, as well as economic drivers. Whatever the reason behind the migrations, remittances provide some crucial contributions to poor households left at home. Kosovo serves as a powerful example of how conflicts increase the number of vulnerable people and how remittances play a major role in helping individuals to fulfill their basic needs in such contexts.

Our results show that remittances are an effective mechanism in helping to alleviate poverty in Kosovo by enhancing the consumption level of the poorest households over a number of years. Due to the paucity of household surveys in post-civil war contexts, it would be useful to pursue further research in Kosovo in order to formulate the most appropriate policies; much remains to be understood about how remittances relate to rebuilding and to sustaining peace. A challenge here is the lack of longitudinal data in Kosovo which would allow us to track individuals over time and to study how their living standards evolved immediately and several years after the receipt of remittances. Also, it would be useful to consider the consequences not only of the receipt of transfers (extensive margin), but also the amount remitted (intensive margin). Clearly, more detailed data would be welcome in order to further analyze the consequences which transfers from abroad may have for their recipients. 


\section{References}

Adams R.H., Cuecuecha A., (2010a), "The economic impact of international remittances on poverty and household consumption and investment in Indonesia", World Bank Policy Research Working Paper 5433, Washington.

Adams R.H., Cuecuecha A., (2010b), "Remittances, household expenditure and investment in Guatemala", World Development, vol. 38, pp. 1626-1641.

Adams R.H., Lopez-Feldman A., Mora J., Taylor J.E., (2008), Remittances, inequality and poverty: Evidence from rural Mexico, in J. DeWind and J. Holdaway, eds., Migration and Development Within and Across Borders: Research and Policy Perspectives on Internal and International Migration, Geneva: International Organization for Migration, pp. 101-130.

Adams R.H., Page J., (2005). "Do international migration and remittances reduce poverty in developing countries?", World Development, vol. 33, 1645- 1669.

Arango J., Kouaouci A., Massey D.S., Pellegrino A., Taylor J.E, (1996), "International migration and community development", Population Index, vol. 62, pp. 397-418.

Bhaumik S.K., Gang I.N., Yun M.S., (2006), "Ethnic conflict and economic disparity: Serbians and Albanians in Kosovo", Journal of Comparative Economics, vol. 34, pp. 754-773.

Brown R., Jimenez E., (2008), "Estimating the net effects of migration and remittances on poverty and inequality: Comparison of Fiji and Tonga", Journal of International Development, vol. 20, pp. 547-571.

Dimova R., Wolff F.C., (2015), "Remittances and chain migration: Longitudinal evidence from Bosnia and Herzegovina", Journal of Development Studies, vol. 51, pp. 554-568.

Dolfin S., Genicot G., (2010), "What do networks do? The role of networks on migration and "coyote" use", Review of Development Economics, vol. 14, pp. 343-359.

Duval L., Wolff F.C., (2015), "Ethnicity and remittances: Evidence from Kosovo", Journal of Comparative Economics, vol. 43, pp. 334-349.

Edwards A.C., Ureta M.A., (2003), "International migration, remittances, and schooling: Evidence from El Salvador", Journal of Development Economics, vol. 72, pp. 429-461.

Epstein G.S, Gang I., (2006), "The influence of others on migration plans", Review of Development Economics, vol. 10, pp. 652-665.

European Stability Initiative, (2006), "Cutting the lifeline: Migration, families and the future of Kosovo", ESI Report, European Stability Initiative.

Firpo S., (2007), "Efficient semiparametric estimation of quantile treatment effects", Econometrica, vol. 75, pp. 259-276.

Frölich M., Melly B., (2010), "Estimation of quantile treatment effects with Stata", Stata Journal, vol. 10 , pp. 423-457.

Hildebrandt N., McKenzie D., (2005), "The effects of migration on child health in Mexico", Economia, vol. 6, pp. 257-289.

Koenker R., Bassett G., (1978), "Regression quantiles”, Econometrica, vol. 46, pp. 33-50.

Mohapatra S., Ratha D., Silwal A., (2010), "Outlook for remittance flows 2011-12. Recovery after the crisis, but risks lie ahead", Migration and Development Brief, $\mathrm{n}^{\circ} 13$.

Mohapatra S., Joseph G., Ratha D., (2012), "Remittances and natural disasters: ex-post response and contribution to ex-ante preparedness", Environment, Development and Sustainability, vol. 14, pp. 365-387.

Osili U.O., (2004), "Migrants and housing investments: theory and evidence from Nigeria", Economic Development and Cultural Change, vol. 52, pp. 821-849.

Piracha M., Saraogi A., (2012), "The determinants of remittances: Evidence from Moldova", Oxford Development Studies, vol. 40, pp. 467-491.

Rapoport H., Docquier F., (2006), The economics of migrants' remittances, in J. Mercier-Ythier and S.C. Kolm, eds., Handbook on the economics of giving, altruism and reciprocity, Amsterdam: Elsevier-North Holland, pp. 1135-1198. 
Thornton R.J., Iness J.T., (1989), "Interpreting semilogarithmic regression coefficients in labor research", Journal of Labor Research, vol. 10, pp. 443-447.

UNDP (2011), Kosovo Remittance Study 2010, UBO Consulting, Pristina.

Woodruff C., Zenteno R., (2007), "Migration networks and microenterprises in Mexico", Journal of Development Economics, vol. 82, pp. 509-528.

World Bank, (2001), Basic information document. Kosovo Living Standards Measurement Study Survey 2000, Poverty and Human Resources Development Research Group.

World Bank, (2013), "Migration and Remittance Flows: Recent Trends and Outlook, 2013-2016", Migration and Development Brief.

Yang D., Choi H., (2007), "Are remittances insurance? Evidence from rainfall shocks in the Philippines", World Bank Economic Review, vol. 21, pp. 219-248. 
Figure 1. Use of remittances

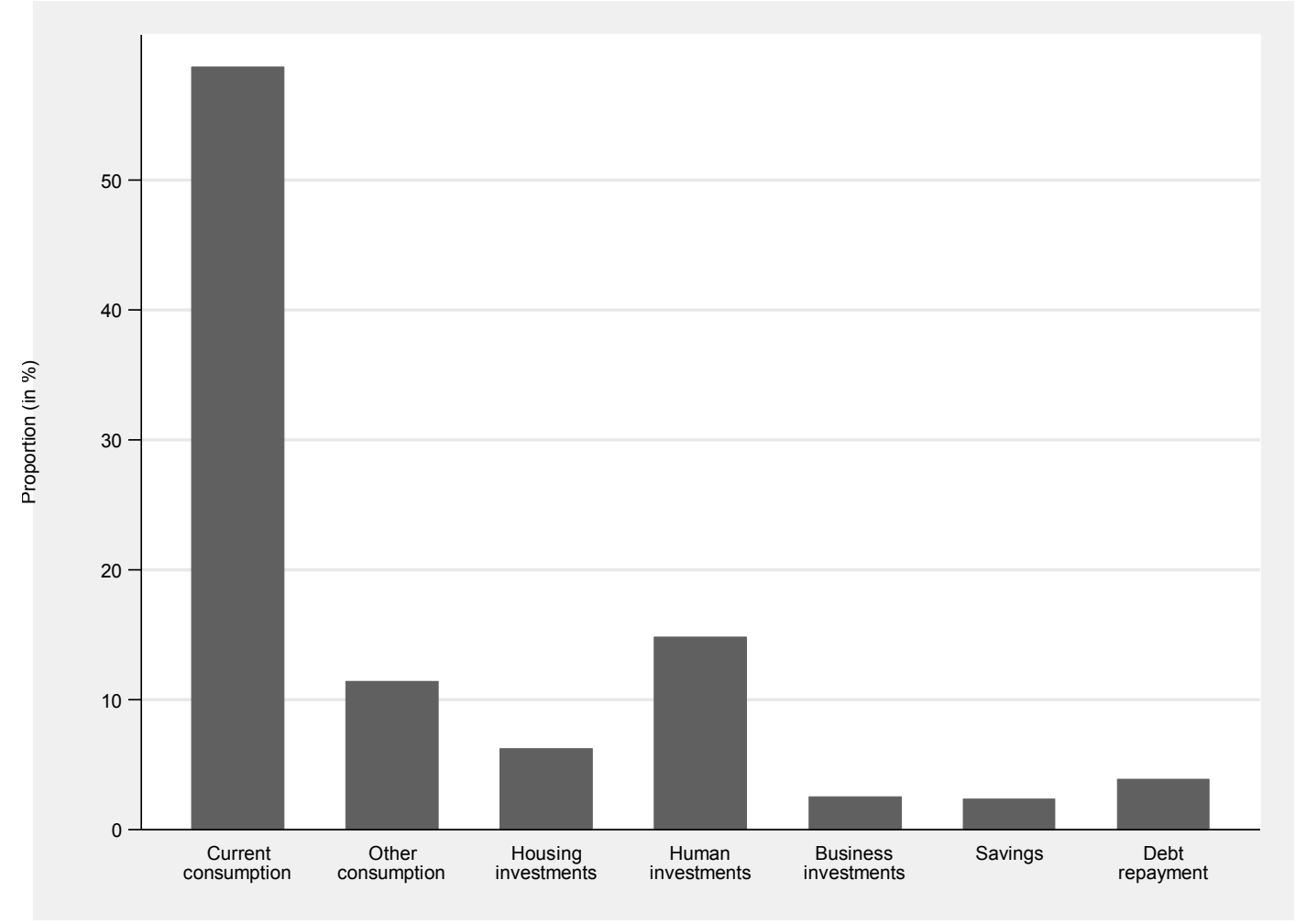

Source: Authors' calculations, UNDP Kosovo Remittance Study 2010. 
Figure 2. Contribution of remittances to total household resources, by income decile

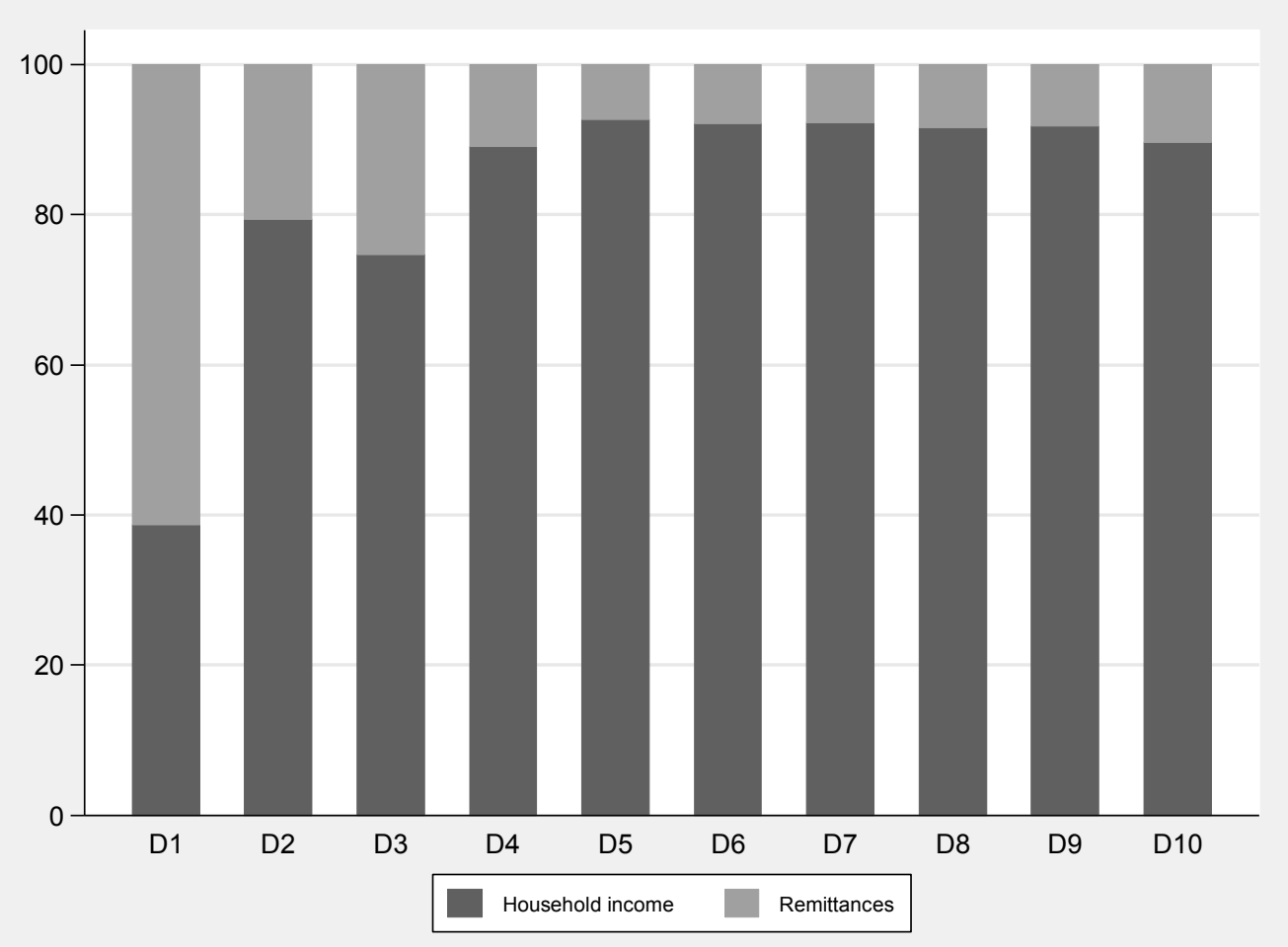

Source: Authors' calculations, UNDP Kosovo Remittance Study 2010. 
Figure 3. Unconditional QTE estimates of remittances, with exogenous transfers

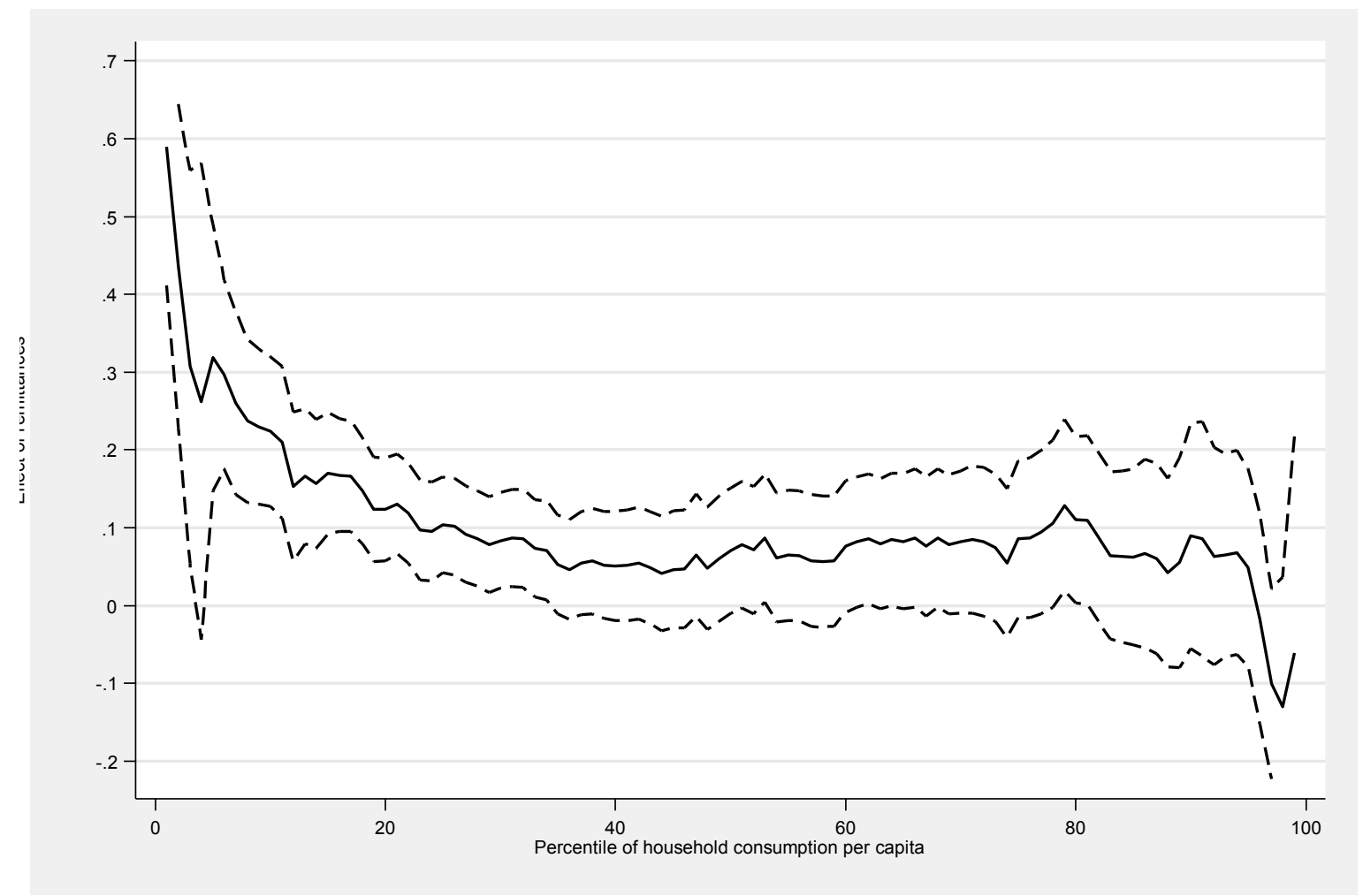

Source: Authors' calculations, UNDP Kosovo Remittance Study 2010. 
Table 1. Subjective contribution of remittances to household welfare

\begin{tabular}{lllll}
\hline Subjective contribution & \multicolumn{2}{l}{ Household income } & \multirow{2}{*}{ All } \\
\cline { 2 - 4 } & Less than $€ 200$ & $€ 200-600$ & More than $€ 600$ & \\
\hline Very small (less than 15\%) & 6.7 & 12.1 & 6.4 & 9.5 \\
Small (16-35\%) & 8.3 & 11.8 & 10.6 & 10.5 \\
Mid-level (36-65\%) & 42.8 & 44.4 & 37.2 & 42.8 \\
Large (66-85\%) & 24.2 & 20.9 & 27.7 & 22.9 \\
Very large (over 85\%) & 18.0 & 10.9 & 18.1 & 14.2 \\
\hline
\end{tabular}

Source: Authors' calculations, UNDP Kosovo Remittance Study 2010. 
Table 2. Descriptive statistics of the sample

\begin{tabular}{lllll}
\hline Variables & All & Remittances & No remittances & Difference \\
\hline Household consumption per capita (log) & 4.622 & 4.705 & 4.604 & $0.102^{* * *}$ \\
Head : Female & 0.155 & 0.199 & 0.146 & $0.053^{* * *}$ \\
Head : Age & 48.954 & 51.835 & 48.334 & $3.501^{* * *}$ \\
Head : Married & 0.845 & 0.828 & 0.848 & -0.020 \\
Size of the household & 5.084 & 5.870 & 4.915 & $0.956^{* * *}$ \\
Proportion of persons aged 0-12 years & 0.132 & 0.131 & 0.132 & -0.001 \\
Proportion of persons aged $>60$ years & 0.103 & 0.118 & 0.100 & $0.018^{* *}$ \\
Head : Primary school & 0.283 & 0.365 & 0.265 & $0.101^{* * *}$ \\
Head : Secondary school & 0.461 & 0.416 & 0.471 & $-0.055^{* * *}$ \\
Head : More than secondary school & 0.257 & 0.219 & 0.265 & $-0.046^{* *}$ \\
Head : Unemployed & 0.242 & 0.343 & 0.220 & $0.123^{* * *}$ \\
Head : Employed in public sector & 0.193 & 0.141 & 0.204 & $-0.063^{* * *}$ \\
Head : Employed in private sector & 0.308 & 0.240 & 0.323 & $-0.083^{* * *}$ \\
Head : Employer or self-employed & 0.081 & 0.042 & 0.089 & $-0.046^{* * *}$ \\
Head : Others (pensioner, housewife, ...) & 0.177 & 0.234 & 0.164 & $0.070^{* * *}$ \\
Urban area & 0.517 & 0.477 & 0.525 & $-0.049^{* *}$ \\
Albanian & 0.752 & 0.889 & 0.722 & $0.167^{* * *}$ \\
Serb & 0.150 & 0.051 & 0.172 & $-0.121^{* * *}$ \\
Other minorities & 0.098 & 0.061 & 0.106 & $-0.046^{* * *}$ \\
\hline Number of observations & 4,000 & 709 & 3,291 & \\
\hline
\end{tabular}

Source: Authors' calculations, UNDP Kosovo Remittance Study 2010. 
Table 3. Estimates of the log of per capita consumption

\begin{tabular}{|c|c|c|c|c|c|c|}
\hline \multirow[t]{2}{*}{ Variables } & \multirow[t]{2}{*}{ OLS } & \multicolumn{5}{|c|}{ Quantile regressions } \\
\hline & & P10 & $\mathrm{P} 25$ & $\mathrm{P} 50$ & $\mathrm{P} 75$ & $\mathrm{P} 90$ \\
\hline Receipt of remittances & $\begin{array}{l}0.167^{* * *} \\
(7.00)\end{array}$ & $\begin{array}{l}0.202^{* * *} \\
(5.44)\end{array}$ & $\begin{array}{l}0.156^{* * *} \\
(6.68)\end{array}$ & $\begin{array}{l}0.134^{* * *} \\
(4.62)\end{array}$ & $\begin{array}{l}0.135^{* * *} \\
(4.44)\end{array}$ & $\begin{array}{l}0.115^{* *} \\
(2.47)\end{array}$ \\
\hline Head: Female & $\begin{array}{l}-0.004 \\
(-0.13)\end{array}$ & $\begin{array}{l}0.071^{*} \\
(1.79)\end{array}$ & $\begin{array}{l}0.015 \\
(0.59)\end{array}$ & $\begin{array}{l}0.036 \\
(1.11)\end{array}$ & $\begin{array}{l}-0.011 \\
(-0.30)\end{array}$ & $\begin{array}{l}-0.069 \\
(-1.25)\end{array}$ \\
\hline Head: Age & $\begin{array}{l}-0.000 \\
(-0.43)\end{array}$ & $\begin{array}{l}0.002^{*} \\
(1.66)\end{array}$ & $\begin{array}{l}0.000 \\
(0.22)\end{array}$ & $\begin{array}{l}0.000 \\
(0.11)\end{array}$ & $\begin{array}{l}-0.001 \\
(-1.03)\end{array}$ & $\begin{array}{l}-0.001 \\
(-0.66)\end{array}$ \\
\hline Head: Married & $\begin{array}{l}0.029 \\
(1.10)\end{array}$ & $\begin{array}{l}-0.020 \\
(-0.51)\end{array}$ & $\begin{array}{l}0.002 \\
(0.08)\end{array}$ & $\begin{array}{l}0.036 \\
(1.12)\end{array}$ & $\begin{array}{l}0.055^{*} \\
(1.65)\end{array}$ & $\begin{array}{l}0.036 \\
(0.71)\end{array}$ \\
\hline Size of the household & $\begin{array}{l}-0.045^{* * *} \\
(-11.10)\end{array}$ & $\begin{array}{l}-0.102^{* * *} \\
(-19.57)\end{array}$ & $\begin{array}{l}-0.069 * * * \\
(-19.93)\end{array}$ & $\begin{array}{l}-0.045^{* * *} \\
(-9.25)\end{array}$ & $\begin{array}{l}-0.031 * * * \\
(-5.11)\end{array}$ & $\begin{array}{l}-0.022^{* *} \\
(-2.19)\end{array}$ \\
\hline $\begin{array}{l}\text { Proportion of persons aged 0-12 } \\
\text { years }\end{array}$ & $\begin{array}{l}-0.488^{* * *} \\
(-9.36)\end{array}$ & $\begin{array}{l}-0.185^{* *} \\
(-2.50)\end{array}$ & $\begin{array}{l}-0.241 * * * \\
(-4.95)\end{array}$ & $\begin{array}{l}-0.374 * * * \\
(-5.95)\end{array}$ & $\begin{array}{l}-0.472^{* * *} \\
(-6.87)\end{array}$ & $\begin{array}{l}-0.660 * * * \\
(-6.10)\end{array}$ \\
\hline $\begin{array}{l}\text { Proportion of persons aged }>60 \\
\text { years }\end{array}$ & $\begin{array}{l}-0.127^{* *} \\
(-2.40)\end{array}$ & $\begin{array}{l}-0.253^{* * *} \\
(-3.06)\end{array}$ & $\begin{array}{l}-0.155^{* * *} \\
(-3.07)\end{array}$ & $\begin{array}{l}-0.067 \\
(-1.05)\end{array}$ & $\begin{array}{l}-0.067 \\
(-0.97)\end{array}$ & $\begin{array}{l}-0.133 \\
(-1.27)\end{array}$ \\
\hline Head: Secondary school & $\begin{array}{l}0.041^{*} \\
(1.73)\end{array}$ & $\begin{array}{l}0.183^{* * *} \\
(5.06)\end{array}$ & $\begin{array}{l}0.103 * * * \\
(4.56)\end{array}$ & $\begin{array}{l}0.062^{* *} \\
(2.15)\end{array}$ & $\begin{array}{l}0.015 \\
(0.50)\end{array}$ & $\begin{array}{l}-0.045 \\
(-0.95)\end{array}$ \\
\hline Head: More than secondary school & $\begin{array}{l}0.124^{* * *} \\
(4.53)\end{array}$ & $\begin{array}{l}0.188^{* * *} \\
(4.55)\end{array}$ & $\begin{array}{l}0.141 * * * \\
(5.44)\end{array}$ & $\begin{array}{l}0.128 * * * \\
(3.86)\end{array}$ & $\begin{array}{l}0.144^{* * *} \\
(4.10)\end{array}$ & $\begin{array}{l}0.171^{* * *} \\
(3.28)\end{array}$ \\
\hline Head: Unemployed & $\begin{array}{l}-0.078^{* *} \\
(-2.53)\end{array}$ & $\begin{array}{l}-0.212^{* * *} \\
(-4.49)\end{array}$ & $\begin{array}{l}-0.151^{* * *} \\
(-5.03)\end{array}$ & $\begin{array}{l}-0.053 \\
(-1.43)\end{array}$ & $\begin{array}{l}-0.033 \\
(-0.84)\end{array}$ & $\begin{array}{l}-0.040 \\
(-0.66)\end{array}$ \\
\hline Head: Employed in public sector & $\begin{array}{l}0.128 * * * \\
(3.84)\end{array}$ & $\begin{array}{l}0.173^{* * *} \\
(3.34)\end{array}$ & $\begin{array}{l}0.123 * * * \\
(3.77)\end{array}$ & $\begin{array}{l}0.091^{* *} \\
(2.25)\end{array}$ & $\begin{array}{l}0.098^{* *} \\
(2.31)\end{array}$ & $\begin{array}{l}0.097 \\
(1.53)\end{array}$ \\
\hline Head: Employed in private sector & $\begin{array}{l}0.156^{* * * *} \\
(4.94)\end{array}$ & $\begin{array}{l}0.099 * * \\
(2.00)\end{array}$ & $\begin{array}{l}0.067^{* *} \\
(2.15)\end{array}$ & $\begin{array}{l}0.136 * * * \\
(3.58)\end{array}$ & $\begin{array}{l}0.164^{* * *} \\
(4.13)\end{array}$ & $\begin{array}{l}0.181^{* * *} \\
(3.00)\end{array}$ \\
\hline Head: Employer or self-employed & $\begin{array}{l}0.167^{* * *} \\
(4.04)\end{array}$ & $\begin{array}{l}0.137^{* *} \\
(2.20)\end{array}$ & $\begin{array}{l}0.104^{* * *} \\
(2.63)\end{array}$ & $\begin{array}{l}0.170^{* * *} \\
(3.42)\end{array}$ & $\begin{array}{l}0.172 * * * \\
(3.23)\end{array}$ & $\begin{array}{l}0.213^{* * *} \\
(2.59)\end{array}$ \\
\hline Urban area & $\begin{array}{l}0.158^{* * *} \\
(8.58)\end{array}$ & $\begin{array}{l}0.013 \\
(0.47)\end{array}$ & $\begin{array}{l}0.074^{* * *} \\
(4.19)\end{array}$ & $\begin{array}{l}0.137^{* * *} \\
(6.16)\end{array}$ & $\begin{array}{l}0.184^{* * *} \\
(7.81)\end{array}$ & $\begin{array}{l}0.212^{* * *} \\
(5.89)\end{array}$ \\
\hline Head: Serb & $\begin{array}{l}0.036 \\
(1.28)\end{array}$ & $\begin{array}{l}0.079 * \\
(1.84)\end{array}$ & $\begin{array}{l}0.003 \\
(0.10)\end{array}$ & $\begin{array}{l}-0.011 \\
(-0.33)\end{array}$ & $\begin{array}{l}-0.037 \\
(-1.01)\end{array}$ & $\begin{array}{l}0.028 \\
(0.51)\end{array}$ \\
\hline Head: Other minorities & $\begin{array}{l}-0.351^{* * *} \\
(-11.06)\end{array}$ & $\begin{array}{l}-0.275^{* * *} \\
(-5.86)\end{array}$ & $\begin{array}{l}-0.265^{* * *} \\
(-8.76)\end{array}$ & $\begin{array}{l}-0.268^{* * *} \\
(-6.98)\end{array}$ & $\begin{array}{l}-0.281 * * * \\
(-6.94)\end{array}$ & $\begin{array}{l}-0.354^{* * *} \\
(-5.71)\end{array}$ \\
\hline Constant & $\begin{array}{l}4.667 * * * \\
(73.62)\end{array}$ & $\begin{array}{l}4.199 * * * \\
(44.42)\end{array}$ & $\begin{array}{l}4.435^{* * *} \\
(72.33)\end{array}$ & $\begin{array}{l}4.569 * * * \\
(59.71)\end{array}$ & $\begin{array}{l}4.939 * * * \\
(60.60)\end{array}$ & $\begin{array}{l}5.380 * * * \\
(42.89)\end{array}$ \\
\hline Observations & 4000 & 4000 & 4000 & 4000 & 4000 & 4000 \\
\hline Pseudo $R^{2}-R^{2}$ & 0.194 & 0.179 & 0.112 & 0.099 & 0.105 & 0.114 \\
\hline
\end{tabular}

Source: Authors' calculations, UNDP Kosovo Remittance Study 2010.

Note: significance levels are $1 \%(* * *), 5 \%(* *)$ and $10 \%(*)$. Each regression includes a set of regional dummies. 
Table 4. Quantile estimates of the log of per capita consumption - 2000 and 2010

\begin{tabular}{|c|c|c|c|c|c|c|}
\hline \multirow[t]{2}{*}{ Variables } & \multirow[t]{2}{*}{ OLS } & \multicolumn{5}{|c|}{ Quantile regressions } \\
\hline & & P10 & $\mathrm{P} 25$ & P50 & P75 & $\mathrm{P} 90$ \\
\hline Receipt of remittances & $\begin{array}{l}0.158^{* * *} \\
(7.10)\end{array}$ & $\begin{array}{l}0.220 * * * \\
(6.55)\end{array}$ & $\begin{array}{l}0.208^{* * *} \\
(7.77)\end{array}$ & $\begin{array}{l}0.140^{* * *} \\
(5.58)\end{array}$ & $\begin{array}{l}0.105^{* * *} \\
(3.30)\end{array}$ & $\begin{array}{l}0.080^{* *} \\
(2.18)\end{array}$ \\
\hline Year 2010 & $\begin{array}{l}0.113^{* * *} \\
(6.94)\end{array}$ & $\begin{array}{l}0.083^{* * *} \\
(3.34)\end{array}$ & $\begin{array}{l}0.100 * * * \\
(5.10)\end{array}$ & $\begin{array}{l}0.097 * * * \\
(5.22)\end{array}$ & $\begin{array}{l}0.125^{* * *} \\
(5.27)\end{array}$ & $\begin{array}{l}0.175^{* * *} \\
(6.22)\end{array}$ \\
\hline Receipt of remittances * Year 2010 & $\begin{array}{l}0.014 \\
(0.45)\end{array}$ & $\begin{array}{l}0.002 \\
(0.03)\end{array}$ & $\begin{array}{l}-0.055 \\
(-1.44)\end{array}$ & $\begin{array}{l}0.016 \\
(0.46)\end{array}$ & $\begin{array}{l}0.059 \\
(1.31)\end{array}$ & $\begin{array}{l}0.080 \\
(1.55)\end{array}$ \\
\hline Head: Female & $\begin{array}{l}0.001 \\
(0.03)\end{array}$ & $\begin{array}{l}0.053 \\
(1.57)\end{array}$ & $\begin{array}{l}0.034 \\
(1.27)\end{array}$ & $\begin{array}{l}0.030 \\
(1.20)\end{array}$ & $\begin{array}{l}-0.013 \\
(-0.39)\end{array}$ & $\begin{array}{l}-0.045 \\
(-1.18)\end{array}$ \\
\hline Head: Age & $\begin{array}{l}0.001 * \\
(1.78)\end{array}$ & $\begin{array}{l}0.003 * * * \\
(3.55)\end{array}$ & $\begin{array}{l}0.002^{* * *} \\
(3.02)\end{array}$ & $\begin{array}{l}0.001 \\
(1.22)\end{array}$ & $\begin{array}{l}0.001 \\
(1.52)\end{array}$ & $\begin{array}{l}-0.000 \\
(-0.42)\end{array}$ \\
\hline Head: Married & $\begin{array}{l}0.003 \\
(0.15)\end{array}$ & $\begin{array}{l}-0.002 \\
(-0.07)\end{array}$ & $\begin{array}{l}0.032 \\
(1.32)\end{array}$ & $\begin{array}{l}0.029 \\
(1.23)\end{array}$ & $\begin{array}{l}-0.025 \\
(-0.84)\end{array}$ & $\begin{array}{l}-0.043 \\
(-1.24)\end{array}$ \\
\hline Size of the household & $\begin{array}{l}-0.042^{* * *} \\
(-15.84)\end{array}$ & $\begin{array}{l}-0.068^{* * *} \\
(-18.95)\end{array}$ & $\begin{array}{l}-0.051^{* * *} \\
(-17.34)\end{array}$ & $\begin{array}{l}-0.040^{* * *} \\
(-13.28)\end{array}$ & $\begin{array}{l}-0.034^{* * *} \\
(-7.89)\end{array}$ & $\begin{array}{l}-0.032^{* * *} \\
(-5.75)\end{array}$ \\
\hline Proportion of persons aged $0-12$ years & $\begin{array}{l}-0.387^{* * *} \\
(-10.36)\end{array}$ & $\begin{array}{l}-0.171^{* * *} \\
(-3.00)\end{array}$ & $\begin{array}{l}-0.237^{* * *} \\
(-5.30)\end{array}$ & $\begin{array}{l}-0.361^{* * *} \\
(-8.54)\end{array}$ & $\begin{array}{l}-0.399 * * * \\
(-7.30)\end{array}$ & $\begin{array}{l}-0.524 * * * \\
(-7.91)\end{array}$ \\
\hline Proportion of persons aged $>60$ years & $\begin{array}{l}-0.299 * * * \\
(-8.11)\end{array}$ & $\begin{array}{l}-0.351^{* * *} \\
(-6.17)\end{array}$ & $\begin{array}{l}-0.318^{* * *} \\
(-7.17)\end{array}$ & $\begin{array}{l}-0.225^{* * *} \\
(-5.40)\end{array}$ & $\begin{array}{l}-0.234^{* * *} \\
(-4.44)\end{array}$ & $\begin{array}{l}-0.313 * * * \\
(-5.16)\end{array}$ \\
\hline Head: Secondary school & $\begin{array}{l}0.087^{* * *} \\
(5.10)\end{array}$ & $\begin{array}{l}0.196 * * * \\
(7.30)\end{array}$ & $\begin{array}{l}0.142 * * * \\
(6.79)\end{array}$ & $\begin{array}{l}0.104^{* * *} \\
(5.39)\end{array}$ & $\begin{array}{l}0.058^{* *} \\
(2.37)\end{array}$ & $\begin{array}{l}0.027 \\
(0.92)\end{array}$ \\
\hline Head: More than secondary school & $\begin{array}{l}0.184^{* * *} \\
(9.35)\end{array}$ & $\begin{array}{l}0.192^{* * *} \\
(6.30)\end{array}$ & $\begin{array}{l}0.205^{* * *} \\
(8.61)\end{array}$ & $\begin{array}{l}0.187^{* * *} \\
(8.42)\end{array}$ & $\begin{array}{l}0.217^{* * *} \\
(7.81)\end{array}$ & $\begin{array}{l}0.196 * * * \\
(6.20)\end{array}$ \\
\hline Head: Unemployed & $\begin{array}{l}-0.096^{* * *} \\
(-4.26)\end{array}$ & $\begin{array}{l}-0.146^{* * *} \\
(-4.17)\end{array}$ & $\begin{array}{l}-0.117^{* * *} \\
(-4.26)\end{array}$ & $\begin{array}{l}-0.080 * * * \\
(-3.14)\end{array}$ & $\begin{array}{l}-0.040 \\
(-1.26)\end{array}$ & $\begin{array}{l}-0.033 \\
(-0.90)\end{array}$ \\
\hline Head: Employed in public sector & $\begin{array}{l}0.119 * * * \\
(5.18)\end{array}$ & $\begin{array}{l}0.218^{* * *} \\
(6.09)\end{array}$ & $\begin{array}{l}0.102 * * * \\
(3.62)\end{array}$ & $\begin{array}{l}0.098^{* * *} \\
(3.80)\end{array}$ & $\begin{array}{l}0.087^{* * *} \\
(2.73)\end{array}$ & $\begin{array}{l}0.081^{* *} \\
(2.19)\end{array}$ \\
\hline Head: Employed in private sector & $\begin{array}{l}0.133^{* * *} \\
(6.22)\end{array}$ & $\begin{array}{l}0.149 * * * \\
(4.46)\end{array}$ & $\begin{array}{l}0.075 * * * \\
(2.87)\end{array}$ & $\begin{array}{l}0.127^{* * *} \\
(5.28)\end{array}$ & $\begin{array}{l}0.148 * * * \\
(4.98)\end{array}$ & $\begin{array}{l}0.130 * * * \\
(3.81)\end{array}$ \\
\hline Head: Employer or self-employed & $\begin{array}{l}0.226 * * * \\
(7.79)\end{array}$ & $\begin{array}{l}0.256^{* * *} \\
(5.77)\end{array}$ & $\begin{array}{l}0.201 * * * \\
(5.72)\end{array}$ & $\begin{array}{l}0.226^{* * *} \\
(6.90)\end{array}$ & $\begin{array}{l}0.243^{* * *} \\
(5.92)\end{array}$ & $\begin{array}{l}0.283^{* * *} \\
(5.89)\end{array}$ \\
\hline Urban area & $\begin{array}{l}0.116^{* * *} \\
(8.52)\end{array}$ & $\begin{array}{l}0.060 * * * \\
(2.87)\end{array}$ & $\begin{array}{l}0.083^{* * *} \\
(4.99)\end{array}$ & $\begin{array}{l}0.107^{* * *} \\
(6.94)\end{array}$ & $\begin{array}{l}0.119 * * * \\
(6.16)\end{array}$ & $\begin{array}{l}0.100 * * * \\
(4.44)\end{array}$ \\
\hline Head: Serb & $\begin{array}{l}-0.025 \\
(-1.25)\end{array}$ & $\begin{array}{l}-0.003 \\
(-0.10)\end{array}$ & $\begin{array}{l}-0.001 \\
(-0.06)\end{array}$ & $\begin{array}{l}-0.036 \\
(-1.56)\end{array}$ & $\begin{array}{l}-0.086 * * * \\
(-2.95)\end{array}$ & $\begin{array}{l}-0.043 \\
(-1.26)\end{array}$ \\
\hline Head: Other minorities & $\begin{array}{l}-0.290 * * * \\
(-11.25)\end{array}$ & $\begin{array}{l}-0.340 * * * \\
(-8.52)\end{array}$ & $\begin{array}{l}-0.276^{* * *} \\
(-8.79)\end{array}$ & $\begin{array}{l}-0.224^{* * *} \\
(-7.69)\end{array}$ & $\begin{array}{l}-0.230 * * * \\
(-6.25)\end{array}$ & $\begin{array}{l}-0.242^{* * *} \\
(-5.62)\end{array}$ \\
\hline Constant & $\begin{array}{l}4.524 * * * \\
(91.94)\end{array}$ & $\begin{array}{l}3.829 * * * \\
(49.54)\end{array}$ & $\begin{array}{l}4.122 * * * \\
(68.49)\end{array}$ & $\begin{array}{l}4.450 * * * \\
(79.89)\end{array}$ & $\begin{array}{l}4.853^{* * *} \\
(67.85)\end{array}$ & $\begin{array}{l}5.394 * * * \\
(62.50)\end{array}$ \\
\hline Observations & 6880 & 6880 & 6880 & 6880 & 6880 & 6880 \\
\hline Pseudo $R^{2}-R^{2}$ & 0.199 & 0.147 & 0.115 & 0.099 & 0.099 & 0.114 \\
\hline
\end{tabular}

Source: Authors' calculations, LSMS Kosovo 2000 and UNDP Kosovo Remittance Study 2010.

Note: Estimates from quantile and OLS regressions (standard errors are not reported). Significance levels are $1 \%(* * *), 5 \%$ $\left({ }^{* *}\right)$ and $10 \%(*)$. Each regression includes a set of regional dummies. 